\title{
PURCHASING DECISION CRITERIA FOR WOODEN FURNITURE IN QUERETARO, MEXICO
}

Reséndiz Martínez Joel, Autonomous University of Queretaro, Mexico Cabello Cervantes León Martín, Autonomous University of Queretaro, Mexico

dx.doi.org/10.18374/JIMS-21-1.5

\begin{abstract}
Knowledge of the market and the criteria consumers carry out to decide on their purchases of wooden furniture, is a strategic factor of manufacturing organizations. The consumer's behavior information is integrated into the design of innovative furniture. Innovation is a relevant factor for wooden furniture manufacturing companies to stay in the market; this involves developing products and promoting the offer by attending to the consumers' expectations derived from their purchasing behavior.
\end{abstract}

Keywords: purchase, wooden furniture, Mexico 